\section{Influence and Role of Business Reputation (Goodwill) on the Development of International Business}

\section{Tetyana HNATIUK ${ }^{1}$}

${ }^{1}$ Assistant of the Department of European Law and Comparative Law, Yuri Fedkovych National University, Chernivtsi, Ukraine. E-mail: t.gnatuyk@,chnu.edu.ua
Abstract: International business historically and logically arises as a result of the development and deepening of the international division of labor and the formation of the world market. International business is becoming an allencompassing and pervasive phenomenon of modern civilization. Although there are many examples of international business in which the partners are, on the one hand, a private firm and on the other - a government agency of another country, it is still more typical to consider either inter-firm transactions of this kind, or intra-firm - in the case of if different divisions of the firm are located in different countries and these divisions interact with each other (the most typical in this case - the so-called multinational corporations). International business is based on the ability to benefit from the benefits of interstate (intercountry) business transactions, ie the fact that the sale of this product in another country, or the establishment of a firm of one country of production in another country, or the provision of services jointly by firms etc. provide business parties with more benefits than they would have if they did business in their own countries. This is a key point not only in understanding the nature and specifics of international business itself, but also in explaining the emergence and development of international management as such. Thus, it is a question of motivation of the businessman (manager), and it developed in the context of historical development of a civilization as a whole and its economic kernel - first of all. And definitely the impact of business reputation (goodwill) on the development of such business and its prosperity.

Keywords: international business, goodwill, business reputation, international firm, intangible assets, international enterprise.

How to cite: Hnatiuk, T. (2021). Influence and Role of Business Reputation (Goodwill) on the Development of International Business. Logos Universality Mentality Education Novelty: Law, 9(1), 118-126. https://doi.org/10.18662/lumenlaw/9.1/61 


\section{Introduction}

In the past, the term "business reputation" was interpreted as the ability of an individual to keep documents. The word "reputation" comes from Latin, where "re" - again, and "puture" - to think, to believe. The word "case" has Russian roots. It was borrowed from Bulgarian and translated from Bulgarian literally means "collection of documents". Business reputation is a multifaceted concept, which is why this term has a number of synonyms and similar interpretations, in particular: authority, popularity, recognition, trust, respectability, brand. Currently, the concept of "business reputation" refers to the enterprise as a whole, although in the early twentieth century. the reputation of the enterprise characterized only its owner.

Every international firm in international business strives to succeed, to have a sufficient number of customers, to get maximum profits, that is, to be better than competitors. All this, in fact, is the nature of entrepreneurial activity. However, not all businesses succeed. The reason for this phenomenon is quite simple - successful are those companies that have formed their unique ideology, mission and clearly defined goals, timely and successfully took care of their business reputation in the international arena.

In the economic literature, goodwill is considered as a value measure of the intellectual capital of the enterprise, which is determined only at the time of its sale (IFRS 3). The result of understanding the role of unidentified intangible assets was the introduction of goodwill in the practice of company management. According to the goodwill terminology common in world practice, a firm's "good reputation" is an intangible asset consisting of the company's prestige, business reputation, customer relationship, product range, location, brand, communication values and other factors of real profit growth and increase in market value (Momot, 2007). In fact, goodwill can be seen as a tangible additional benefit due to the quality of business and management efficiency, which give the company a competitive advantage in the industry and the opportunity to earn additional income.

In the course of many years of public opinion research and the work of well-known international companies, the International Reputation Institute (IRI) has managed to form six critical components of the reputation of any international business, the quality of which directly affects the company's success in the market. The relevance of IRI research in post-Soviet countries was confirmed by the annual reputation rating of Russian companies "Expert-100", first conducted in 1999, which featured the same components of reputation. The reputation of any company 
in international business consists of the following six components, which are taken into account by the target groups when forming a stable opinion about the company:
A) emotional attractiveness;
B) product quality;
C) relationships with partners;
E) the reputation of management;
D) social responsibility;
C) financial indicators (Shcherbakova, 2010).

Obviously, the company's reputation is a multifaceted and complex concept. All its components are interconnected and only in a complex can provide adequate impression of the company.

I came to the conclusion that the main components of business reputation in international business can be considered:

- Image as an emotional attraction of the enterprise;

- Goodwill as an economic reflection of business reputation;

- Financial stability of the enterprise so that the partners want to deal with a stable enterprise;

- Organizational culture as an internal source of business reputation;

- The reputation of the leader, which cannot be greater than the reputation of the organization he heads;

- Social responsibility of the enterprise as a necessary condition for trust in the enterprise;

- Product quality, because in market conditions the manufacturer of lowquality products may not have a good business reputation.

Reputation is a kind of credit of trust, a source of attitude of consumers of products (services) to the firm (organization) - its manufacturer. After all, the interests and requirements of the modern consumer are not limited to quality, functional reliability or price of goods (services). They also apply to public recognition, the social face of the firm (organization), confirmed by real cases before the public. Therefore, leading firms (organizations) analyze these factors and invest heavily in their creation and maintenance, because in market conditions, reputation and other intangible assets make up a significant part of the commercial value of the firm (organization).

There is no consensus among scholars as to whether reputation technologies exist or whether only the image can be purposefully constructed. Most 
of them are inclined to the fact that the reputation develops over time, and the image must be constantly and actively formed.

However, the reputation can be formed by well-thought-out consistent actions, and then in everyday life it allows the company to work productively, and in difficult situations - not to suffer large losses. A lasting positive reputation creates a number of additional benefits for the subject (person or organization), namely: they trust him, and they want to listen to those they trust; if there is an alternative choice, he is chosen first; they want to interact with him. Moreover, if an organization with a high reputation makes a mistake, it will not lose credibility with the right actions. Therefore, well-known companies are not afraid to report the error to customers, apologize to them and do everything to ensure that it does not happen again (Gorin, 2006).

\section{Literature review}

Such scientists as Bulyko AN dealt with the issue of determining business reputation. Reisberg BA, Lozovsky LSh, Starodubtseva EB, Mocherny SV, Dulyasova MV, Hannanova TR, Gorin SV, Grebeshkova OM, Szymanska O .V., Solomandina T., Novichenkova L. and others. However, business reputation as an influential factor in the development of international business is interpreted ambiguously and needs research.

\section{Methods}

The purpose of the article is to elucidate the nature of mediation as a value and compare it with the nature of human rights, the rule of law, and pluralistic democracy as basic universal values. It is concretized in the following tasks: elucidation of the properties of basic human values; disclosing the general and distinctive properties of traditional and narrative mediation and determining the place of each of them in several anthroposociocultural values and the ratio of basic human values and mediation.

The purpose of the article and its structure shows a clear application of comparative law, structural analysis and synthesis.

\section{The value of goodwill for international companies}

Goodwill is an intangible asset that has value as a result of the use of better management skills, new technologies, business reputation and connections. Goodwill is an intangible asset. It includes intangible components that increase the value of a single property complex of the enterprise (Chernykh, 2012). 
Goodwill arises from rights, assets and relationships that are intangible in nature and consist throughout the existence of an international enterprise as a single property complex, its activities and business relationships with counterparties (partners). Goodwill consists of many elements. Goodwill is defined according to certain criteria that influence its formation. It is related to the location of the single property complex of the enterprise, the number of potential partners - customers. Therefore, one of the criteria for assessing goodwill is the location of a single property complex of the enterprise and the availability of the appropriate level of infrastructure in the region.

International valuation standards determine the availability of the following types of goodwill: personal and transferable. Personal goodwill is the amount of profit above market valuations, which disappears when transferring (selling) specialized equipment due to a number of financial factors: features of taxation, depreciation policy, the cost of raising funds, etc. A transferable goodwill is an intangible asset that arises from a specific name, business reputation, customer loyalty, location, products, and similar factors that provide economic benefits, and is transferred to a new owner as a result of its sale.

The name of the single property complex of the enterprise is important for the valuation of goodwill. This is especially true of well-known commercial names.

Goodwill in the intangible dimension is an advantage that arises as a result of a well-known commercial name, business reputation of the enterprise. Goodwill may not be transferred by contract to another person or otherwise. But goodwill may be part of a single property complex of the enterprise and may be transferred with it. Commercial goodwill includes all intangible assets of the enterprise, which are aimed at making a profit and increasing the market value of a single property complex of the enterprise (Hnatyuk, 2019).

Goodwill is an additional value to the price of a single property complex of the enterprise in the form of business reputation. The latter is about a single property complex of the enterprise in the process of using it for business activities. Therefore, goodwill should be considered as an integral part of the property complex of the enterprise. By its nature, goodwill cannot exist separately from a single property complex of an enterprise.

The judgment of the European Court of Human Rights of 3 June 1986 (applications № 8543/79, 8674/79, 8675/79 and 8685/79 in Van Marle and Others) states that "goodwill" - accumulated intangible assets of the enterprise, 
covering its name, reputation, business relationships (including clientele), trademarks, etc .; property of the "firm".

Thus, goodwill includes the intangible elements of an enterprise that include the value of business relationships, clientele, trademarks, business reputation, the difference between the carrying amount of the company's assets and liabilities and its fair market value. Goodwill can be defined as a method of valuing assets when acquiring a single property complex of an enterprise, which includes an additional fee to be paid by the buyer over the book value of the company, as trade connections, reputation, use of well-known brands, experience of managers and general technologies are impossible. display in the exact amounts and figures of the balance sheet of the enterprise. Goodwill can also be negative if you buy a company with negative performance and a bad reputation in the market. According to Ukrainian tax law, goodwill defines an intangible asset, the value of which is defined as the difference between the book value of the enterprise's assets and its normal value, as a whole property complex of the enterprise, resulting from the use of better management qualities new technologies, etc. The value of goodwill is not subject to depreciation and is not taken into account when determining the gross costs of the taxpayer.

Therefore, in the event of a breach of the rights to intangible assets, the adverse economic consequences caused to the injured party, including loss of profits, any ill-gotten gains and non-pecuniary damage, must be taken into account.

It should be noted that the case law of the European Court of Human Rights recognizes the right to goodwill, regardless of its formal enshrinement at the level of national law. Subjects of such a right can be both individuals who carry out a certain type of professional and (or) entrepreneurial activity that gives a profit, and legal entities.

Over the past 15 years, the share of the value of goodwill in the total value of "Western" companies has increased from 18 to $82 \%$, analysts note that increasing the business reputation index of the company by $1 \%$ increases its market value by $3 \%$, the value of business reputation increases if it stimulates consumer confidence in their own products. Companies around the world spend millions of dollars to build a good name (Solomanidina, 2005). In view of this, it can be concluded that business reputation is an intangible asset of a modern company, which is strategically important, and therefore refers to strategic assets.

Business reputation is valuable to the company, ie it is a component of its market value. According to Ernst \& Young, Microsoft's share of business 
Influence and Role of Business Reputation (Goodwill) on the Development...

Tetyana HNATIUK

reputation is $84 \%$, Disney - 66\%, Yahoo - 91\%, Nike - 76\% (Zaitsev, 2006). Business reputation cannot be copied or replaced - this is a unique characteristic of each company. A company's business reputation is a rare and unique asset that cannot be bought or acquired without some effort. It is acquired in the process of development and is an integral part of the company.

\section{Goodwill as an intangible component of a single property complex of an international enterprise}

The intangible components of the single property complex of an international enterprise include goodwill, which affects the price of the latter upon its alienation. Goodwill is an intangible asset that is valued through the use of better management, new technology, business reputation and connections. Goodwill is an intangible asset. It includes intangible components that increase the value of a single property complex of the enterprise.

Goodwill arises from rights, assets and relationships that are intangible in nature and consist throughout the existence of an international enterprise as a single property complex, its activities and business relationships with counterparties (partners). Goodwill consists of many elements. Goodwill is defined according to certain criteria that influence its formation. It is related to the location of the single property complex of the enterprise, the number of potential partners - customers. Therefore, one of the criteria for assessing goodwill is the location of a single property complex of the enterprise and the availability of the appropriate level of infrastructure in the region.

The name of the single property complex of the enterprise is important for the valuation of goodwill. This is especially true of well-known international trade names.

Goodwill in the intangible dimension is an advantage that arises as a result of a well-known commercial name, business reputation of the enterprise. Goodwill may not be transferred by contract to another person or otherwise. But goodwill may be part of a single property complex of an international enterprise and may be transferred with it. Commercial goodwill includes all intangible assets of the enterprise, which are aimed at making a profit and increasing the market value of a single property complex of the enterprise.

Goodwill is an additional value to the price of a single property complex of the enterprise in the form of business reputation. The latter is about a single property complex of the enterprise in the process of using it to carry out international business activities. Therefore, goodwill should be considered as an 
integral part of the property complex of an international enterprise. By its nature, goodwill cannot exist separately from a single property complex of an enterprise.

Thus, goodwill includes the intangible elements of an enterprise that include the value of business relationships, clientele, trademarks, business reputation, the difference between the carrying amount of the company's assets and liabilities and its fair market value. Goodwill can be defined as a method of valuing assets when acquiring a single property complex of an enterprise, which includes an additional fee to be paid by the buyer over the book value of the company, as trade connections, reputation, use of well-known brands, experience of managers and general technology are impossible. display in the exact amounts and figures of the balance sheet of the enterprise. Goodwill can also be negative if you acquire an international company with negative performance and a bad reputation in the market. According to Ukrainian tax law, goodwill defines an intangible asset, the value of which is defined as the difference between the book value of the enterprise's assets and its normal value, as a whole property complex of the enterprise, resulting from the use of better management qualities new technologies, etc. The value of goodwill is not subject to depreciation and is not taken into account when determining the gross costs of the taxpayer (Shevchenko, 2009).

\section{Conclusions}

Goodwill is a strategically important asset of the company in international business, as it expresses the value of business reputation. However, the amount of goodwill is not always justified, as there is a possibility of subjective factors, such as ignorance of the parties to the transaction, false valuation of available assets, etc., in the sale and purchase transaction. Therefore, it is objective to assess domestic goodwill as a tool to increase the company's investment attractiveness. International companies should autonomously determine and evaluate the existing components of internally generated goodwill after recognizing and fairly valuing all other tangible and intangible assets, their impact on the amount of cash flows and profits received. The information obtained will be the foundation for assessing the quality of international business, will affect their decisions and financial performance of the enterprise.

\section{References}

Chernykh, O.V. (2012). The essence and evaluation of goodwill as an intangible asset of the enterprise. Strategy and mechanisms regulation of industrial development. 5, 195-203. 
Influence and Role of Business Reputation (Goodwill) on the Development...

Tetyana HNATIUK

Gorin, S.V. (2006) Business reputation of the organization. Phoenix Publishing House.

Hnatyuk, T. M. (2019). The contract of management of the enterprise as a uniform property complex:

dis. Cand. jurid. Science: 12.00.03. https://law.lnu.edu.ua/wpcontent/uploads/2020/06/dysertatsiia.pdf

International Financial Reporting Standard 3 (IFRS 3). IASB Business Association;

Standard, International document of January 1, 2012. https://www.ifrs.org/issuedstandards/list-of-standards/ifrs-3-business-combinations/

Momot, T. (2007). Estimation of business value: modern technologies. Factor.

Shcherbakova, K. (2010). Dilova reputatsiya yak skladova konkurentospromozhnosti pidpryyemstva [Business reputation as a component of enterprise competitiveness]. Economics, 2 (102), 58-63.

Shevchenko, J. M. (2009). Encyclopedia of Civil Law of Ukraine. Nauka.

Solomanidina, T. (2005) Business reputation as one of the most important strategic advantages Companies. Personnel management.

Zaitsev, I. (2006). Good Goodwill. Electronic resource 